\title{
ECO-INNOVATION PATHS: CONVERGENCE OR DIVERGENCE?
}

\author{
Agnieszka KARMAN ${ }^{1^{*}}$, Arkadiusz KIJEK ${ }^{2}$, Tomasz KIJEK ${ }^{2}$ \\ ${ }^{1}$ Institute of Management, Maria Sklodowska Curie University, Lublin, Poland \\ ${ }^{2}$ Institute of Economy, Maria Sklodowska Curie University, Lublin, Poland
}

Received 25 May 2019; accepted 07 June 2020

\begin{abstract}
Eco-innovations comprise new or modified processes, techniques, practices, systems and products allowing environmental harms to be avoided or reduced. They are employed in order for specific social and environmental objectives to be achieved, hence their environmental, social, and institutional significance relating to the achievement of long-term sustainable growth patterns. As a consequence, eco-innovation has great amount of focus from many countries. Adding to the current literature which focuses mainly on the drivers and effects of eco-innovation in the context of developed and developing countries, this paper tries to find an answer to the question about the absolute $\beta$-convergence of eco-innovation. We also consider the spillover effects in the analyses. Our sample consists of 38 countries and relates to the years 2012-2017. We apply the spatial panel models to verify the research hypotheses. The results confirm that there is the absolute $\beta$-convergence in the sample countries. Moreover, we find evidence of positive spillovers of eco-innovation.
\end{abstract}

Keywords: eco-innovation, convergence, sustainable development, spatial model.

JEL Classification: C21, O33, O47, Q55.

\section{Introduction}

Eco-innovation occurs within the limits of common global challenges, including the need to separate growth from the use of resources, to increase the utilization of both new and renewable sources of energy, to increase energy efficiency and to minimize carbon emissions (Lema et al., 2014). They are solutions purposefully planned to reduce impact of manufacturing, consumption and discarding activities on the environment, even if their key incentive is to seize opportunities and take advantage from environmental issues (Neto et al., 2014). In addition, eco-innovation can be viewed as an essential tangible economic facilitator (Montalvo et al., 2011). As far as the issue of eco-innovations is concerned in the literature, most prior research and theoretical papers in this filed are focused on drivers and outcomes of green in-

${ }^{\star}$ Corresponding author. E-mail: agnieszka.karman@poczta.umcs.lublin.pl

Copyright (C) 2020 The Author(s). Published by Vilnius Gediminas Technical University

This is an Open Access article distributed under the terms of the Creative Commons Attribution License (http://creativecommons. org/licenses/by/4.0/), which permits unrestricted use, distribution, and reproduction in any medium, provided the original author and source are credited. 
novations (Díaz-García et al., 2015; del Río et al., 2017; Dahan \& Yusof, 2020). At the macro level the literature underlines the relative importance of eco-innovation in the sustainable development (Kijek \& Kasztelan, 2013; Gente \& Pattanaro, 2019). Moreover, the stream of eco-innovation research is dominated by contributions from developed countries, with a focus on European states (Cuerva et al., 2014; Bartlett \& Trifilova, 2010; Triguero et al., 2013). In case of other countries, there are case studies on eco-innovations in India (Ganapathy et al., 2014), Taiwan (Dong et al., 2014; Cheng et al., 2014), Japan (Sierzchula et al., 2012), and the Republic of Korea (Suh et al., 2005).

Although eco-innovation is universally treated as the most effective mean to solving significant environmental problems, a comprehensive picture of eco-innovation diffusion and convergence remains lacking (Mazzanti, 2018). The study on convergence in regard to ecoinnovation is of particular interest, since specific pathways of eco-innovation trajectories can proceed in various directions depending on specific national starting points. In practice, the application of eco-innovation in different countries may vary due to diverseness of policies, endowments and technological potentials. These differences may be the result of variations in nation-specific attitudes to environmental problems, standing legal regulations and economic instruments, but also a diversified development level of green sectors. As a consequence, countries may converge to multiple equilibria and the share of eco-innovations in countries innovation portfolios will differ. On the other hand, countries with a lower level of ecoinnovation potential compared with more advanced countries can exploit their backward position and increase their rates of growth through diffusion of international technology through imitation. In the global perspective, it is clear that without the catching-up process for the countries whose eco-innovation performance is lagging behind eco-innovation leaders, the expected overall positive effect of environmental innovations cannot be realized.

It is worthy of mention that there is the lack of studies on eco-innovation convergence. Only few studies deal with the issue of catching up process of eco-innovation activities. Unfortunately, these studies have anecdotal character and neglect the spatial and economic complexity of eco-innovation diffusion and/or convergence. In view of the above, the aim of the work is to study the mechanisms of eco-innovation convergence or divergence in the theoretical and empirical manner. In particular, we formulate the hypotheses that provide answers to the following research questions:

1) Is there convergence of eco-innovation drivers among countries?

2) Is there convergence of eco-innovation outputs among countries?

To verify the hypotheses, we test the absolute $\beta$-convergence of eco-innovation in the sample of European and Asian countries, which include developed countries (leaders in ecoinnovation) as well as developing countries. Our analyses apply the input-output approach to portraying eco-innovation efforts. Such methodology allows us to find if there is a tendency to decrease or widen the differences across studied countries regarding the drivers and outputs of eco-innovation. We believe this is a relevant finding, which gives a more clear view of the overall eco-innovation convergence or divergence. To the best of our knowledge, this study is the first to use input-output indicators for eco-convergence analysis at the country level.

Moreover, we consider the spatial dimension of convergence of eco-innovation, since in the line with the geography of innovation and economics of knowledge literature, eco-in- 
novation externalities and dynamics have to be scrutinised in a comprehensive manner. By doing so, the present paper contributes to an improved understanding of the global process of eco-innovation convergence or divergence. The paper may improve the understanding of the dynamics of the paths of eco-innovation, especially the interaction of drivers and outputs. Cross-country comparisons may offer improved models for the enhanced diffusion of eco-innovations, e.g. in terms of environmental policies and inter-institutional cooperation. Such models may constitute benchmarks for the "lagging" countries. Finally, the present study offers an answer to the question whether eco-innovation convergence takes place, and if it is to be expected in the future.

The issue of eco-innovation convergence is also important from a political point of view, since we can expect that the lower the eco-innovation gap between the least advanced countries and the most developed countries is, the more eager eco-innovation laggards would be to obligate to emission reductions objectives during negotiation. What is more, spatial and geography issues should be addressed within eco-innovation analyses. According to Borghesi et al. (2013), there may be convergence in the adoption of cleaner production process techniques in restricted areas where eco-innovation activities, knowledge spillovers, and externalities are concentrated. So far, it seemed that Europe has shown the tendency to act as the main locus of "path creation", while Asian countries have demonstrated "path-following" through fast catching up. This seems to be acknowledged by the following statements: Europe can be the global center of clean energy innovation (Gielen, 2018), Europe is the world leader in innovation through nature-based solutions (Fritz, 2017). No Asian or African company can be found among the 10 most innovative companies in clean energy technologies in 2017 (Bloomberg New Energy Finance, 2017). However, measures pertaining to the emerging eco-innovations do not fully confirm the leading role of EU states. This is valid for environment-related technology patents, early-stage private investment. With regard to investments pertaining to specific issues such as foodstuffs, climate change, water, renewable energy/clean technology, data suggests they were on the rise (in 2014-2016) in European countries (increase of 146\%), in Asia (increase of 198\%) and Japan (increase of 374\%) (Global Sustainable Investment Alliance, 2016). The trend is especially valid for China and Japan. In 2017, for selected countries, investments in clean energy (in billion USD) amounted to the following: China 132, Japan 23, Germany 14, India 11, France 5, Sweden 4 (Statista, 2018). Some Asian regions are clearly pushing ahead, whether it be through the adoption of existing technologies to local markets or by the innovation of entirely new processes designed to protect the environment.

The paper is structured as follows. The link between sustainable development and ecoinnovation is considered in the first section. In particular, we focus on the types of eco-innovations and their importance for sustainable development. Afterwards, we provide theoretical reasoning for hypotheses development. We present the scientific theories underlying the formulation of hypotheses and previous papers on the issue of convergence of eco-innovations. The next sections are devoted to the research: we present research model, research results and discussions. The last part is a summary of the research: conclusion, implication and directions for further research are presented. 


\section{Significance of eco-innovations for sustainable development}

Sustainable development (SD) is a multi-faceted idea, enveloping the interdependence of economic, social and ecological order in socio-economic development, and the necessity of preserving scarce resources for upcoming generations (Kates et al., 2005). Eco-innovation constitutes one of the solutions facilitating the implementation of the concept of SD (Sarkar, 2013; Dahan \& Yusof, 2020). In general, one can identify three groups of definitions of ecoinnovation:

1) definitions related to sustainable development - in general - or related strictly to the environmental aspect (eco-innovation as an instrument);

2) definitions that focus on the life cycle of eco-innovation (eco-innovation as a process);

3) definitions that pertain to environmental gains and/or economic gains (eco-innovation as a source of effects).

The first group involves definitions which comprise the objective orientation, where ecoinnovations are regarded as a mean for sustainable development and targeted at decreasing negative environmental effects. Eco-innovation is all types of innovation, including new skills for environmental improvement, as well as new processes, products and services, new business forms, etc. Additionally, any and all activities related to the reduction of negative effects or the enhancement of a positive effect on the environment while at the same time minimizing the consumption of natural resources are all forms of eco-innovation (Rennings, 2000; Kemp \& Pearson, 2007; Charter \& Clark, 2007; Schiederig et al., 2012). This approach considers eco-innovations as an instrument enabling the achievement of sustainable goals, a mechanism driven by the continuous need for quality improvement and by policy measures and regulations (Hallenga-Brink \& Brezet, 2005) and economic instruments (Tsai \& Liao, 2017).

The second approach takes a process approach. It is based on a sequence of actions including the phase of invention, including generating idea, survey, business analysis and stages of creation of innovation. A number of authors refer to life-cycle analysis as a source of innovative activities (O’Hare, 2010; Motta et al., 2017). The LCA studies provide the means to recognize key points where eco-innovation is recommended; they also help to determine the existing trade-offs between the design of an enduring or a short usage lifetime product.

The approach considering the benefits/threats of eco-innovation is as vital from the perspective of sustainable development (SD). The literature makes heavy reference to environmental gains which may make up an essential objective of innovation. Definitions in this group emphasize the fact that a more efficient utilization of energy and resources results in the reduction in the consumption of resources, energy, and lower production of waste. In addition, some definitions indicate social benefits, e.g. improvement of the quality of life, and economic advantages, e.g. reduced direct costs, ability to attract green rent of the market.

Eco-innovations received special attention in Europe and were seen as one of the significant processes and objectives in achieving the goals of global sustainable development (OECD, 2009). They are regarded as a catalyst for pro-environmental and social changes, but also as a fundamental component of the European Union's policy for sustainable development, fully consistent with the "Europe 2020" Strategy (European Commission, 2010). 
However, developing countries also recognized the need to promote sustainable development in the future through eco-innovation activities (Leitner et al., 2010). Environmental influence may be the result of several social causes, not excluding the sheer size of population, e.g. consumerist attitudes, or non-existent environmental awareness or skills, productivity, jobs (Antonioli et al., 2016). But the industrial metabolism can not be changed by either environmental ethics as such, or regulatory measures, or economic mechanisms, unless all these are geared to the specific point of immediate result in altering the society's metabolism: new technologies and activities that modify the operative structures and ecological features of both production and consumption, and thus ease the stress on resources and environmental sinks or even add to an ecologically benign co-evolution of human society and nature (Huber, 2008). These are why eco-innovations enable and enhance sustainable development.

\section{The issue of the convergence of eco-innovations}

Studies on divergence and convergence date back to the end of the 1970s when Kuhn (1977) focused on the law of scientific discovery and technological invention from the viewpoint of the essential pressure. Later on, the discussion moved to the issues relating to divergence and convergence: policy-making about the convergence of technology (Shin, 2010), strategic management of a transformation in a multi- technology project (Kotnour \& Bollo, 2011), technological convergence as a facor that has an effect on the flow of knowledge between enterprises (Corredoira \& Rosenkopf, 2010), the association which exists between network assets and market entrance in terms of convergence (Lee, 2007), or convergence as a new paradigm (Lee, 2015). Innovation convergence is a learning process that constitutes a continuous disequilibrium between the reference technology and its matching technology, which adjusts the optimal balance between the functions of the two technologies (Lee, 2015).

The learning process needs both vertical and horizontal convergence. Based on a case study of the railway technology in the country of Malaysia, Mohamed et al. (2015) debated that the horizontal convergence pertains to the absorption of innovative foreign technology with the currently use railway technology, whereas the vertical convergence pertains to the step-by-step increase in technology in-depth in the operation and maintenance of a high-speed railway system. Both forms of convergence in the process of technological learning of an institution add to considerable gains. Primarily, technology convergence-inducing innovations are a significant driver of development (Jang, 2009; Lee, 2018). It is often assumed that such innovations eventually boost human well-being as firms address different problems or increase jobs by convergence innovation (Lee, 2015). From the perspective of eco-innovations, their convergence generates economic benefits, enables the economies of scales to be used, determines the performance of international trade, generates jobs. Secondly, whether the incumbents in old industrialized countries retain or even improve their global position, or whether they will be outperformed by new players, makes an enormous difference. The convergence of eco-innovations is associated with creating new pathways and disrupting old ones.

Yet while there is agreement on the positive effect of convergence on the development of the country, past research falls short in studying the conditions of eco-innovation conver- 
gence. Previous works explored the convergence in environmental performance or environmental quality (Camarero et al., 2008; Bimonte, 2009; Salvati \& Zitti, 2008) and convergence of particular type of eco-technologies (Lema et al., 2016; Faria \& Andersen, 2017). It appears that the convergence concept is often viewed as a contextual process rather than a product of social and scientific processes (Corredoira \& Rosenkopf, 2010; Lee, 2007). In fact, convergence of eco-innovation has not been viewed as the exogenous factor in any of the works reviewed.

The convergence innovation processes can also be interpreted (at least) from the perspective of three theories. These theories form the basis of our reasoning.

\subsection{Theory of diffusion of innovations}

In general, the diffusion of an innovation is defined as a process through which an innovation is spread over time among members of a social system through certain channels (Rao \& Kishore, 2010). Rogers (2003) defines the diffusion as "the process by which an innovation is spread through certain channels overtime among members of a social system". Hence, he distinguishes between diffusion and adoption of innovation; in that the former happens within a society, whereas the latter concerns an individual (i.e. a firm or a natural person). In a visual form, the diffusion process is presented as an S-shaped curve: innovations proceed slowly in the initial period. The next phase if a recovery, followed by the saturation phase. Rogers (2003) devised the following categories of adopters: innovators, early adopters, early majority, late majority and laggards, which correspond to different stages of consumer's adoption during the market development-

From an eco-innovation perspective, diffusion leads to ecological modernization (Jänicke, 2008), and in the long term to sustainability transitions (Truffer \& Coenen, 2012; Hazarika \& Zhang, 2019). Fundamental transformation processes occur due to the diffusion of eco-innovation through which established socio-technical systems (branches like power and water supply, or transportation) move to more sustainable modes of production and consumption (Markard et al., 2012). These processes are often explained by structural changes triggered by technology and knowledge, occurring in a specific technological regime. Following Howlett et al. (2013) we believe that country's innovation rate depends on knowledge transfer activities. Government policies, that promote knowledge complementarity and coordination between environmental fields will facilitate the promotion of knowledge transfer, which will result in increase in eco-innovation (Aldieri et al., 2020). The diffusion process also depend on knowledge cumulativeness (Sáez-Martínez et al., 2016), position in relations to technological frontier, absorptive capacity (Aldieri et al., 2018) and other factors (Hojnik \& Ruzzier, 2016).

The diffusion of pro-ecological activities concern, among others, participation in environmental management system, purchasing of green patents, utilization of renewable energy. The "Eco Innovation Activities" indicator used in ASEM Eco Innovation indicates that Asian countries are catching up with "typically" environmentally friendly European countries: Japan - 21, Singapore - 13, China - 33, Norway - 37, France - 25, Germany - 26 (ASEM Eco-Innovation Index [ASEIC], 2015). In Asia - Korea and Japan - are strongly interested in introducing eco-innovation and are eco-innovation active in different ways in relation to 
the regime of sustainable development. With regards to renewable energy industry, growing nations such as China are prevailing the international market with the full support of their governments and are seeing rapid growth. In both regions there is a clear tendency for Asian countries to catch up the European patterns in the scope of implemented ecological activities.

\subsection{Theory of lead market}

The second approach on which this paper was based is a lead market hypothesis (Beise \& Rennings, 2005). The concept of lead market hypothesis focuses on countries which are first to adopt internationally successful innovations. Lead markets are not only characterized by the early adoption of an innovation but also by the fact that they are followed by countries that adopt the same innovation. An innovation's country-specific adoption trend can then be explained by international variations in market factors that determine innovation adoption and vary from country to country. The country implements an innovation first where the adoption stimuli (such as exacted gain, budget, prices) are highest. More and more countries adopt the same innovation as the adoption stimuli increase globally over time (Beise \& Rennings, 2005; Mohamed et al., 2015). The hypothesis of lead market is connected with the endogenous growth theory, according to which a country's technological development path depends on and the country's initial position relative to the technology frontier. For countries which are far from the technology frontier, the increase of technology level results from the country's ability to access and effectively absorb new foreign technologies.

Previous works have suggested that rates of eco-innovation vary according to a country's level of development. As Kemp and Pearson (2007), Huppes et al. (2008) and Arundel and Kemp (2009) claim, developed countries have shown higher eco innovation, since the amount of extra financial input to introduce eco-innovation varies according to the country's level of development. Huber (2008) observes that a country's development level may determine whether eco-innovations are embraced. A country without adequately developed cultural and political consistency, institutional capability, and in particular, as Evans (1995) put it, without state-society synergy based on developmental politics rather than predatory ones, will not be able to implement a complex new technology successfully.

Regarding eco-innovations it should be noted that Asian countries are capable of executing linear paths, just as late-comer enterprises pursue the same trajectory as the one undertaken by their precursors. Schmitz and Altenburg (2016) emphasise that Asian nations, being followers, have learnt from Europe's leaders (and elsewhere) by imitating their innovations. Referring to wind power innovations, Lema et al. (2016) point out that forerunner countries are anticipated to control the world market for these innovations (Rennings, 2014), which may by extension produce similarities across international growth trajectories. From this reason similarities occur in the introduction of technological eco-innovations (in the wind energy sector) in Europe and Asia. These pertain to technical parameters (size, efficiency, and reliability of turbines; Lema et al., 2014). The occurrence of the lead market phenomenon in relation to eco-innovations was also confirmed by Jacob et al. (2005), Quitzow et al. (2014). Beise and Rennings (2005) show that the development of lead markets that pull ecoinnovation is more successful when a country adopts environmental regulations adopted by other countries, which may underline the significance of institutional theory. 


\subsection{Institutional theory}

Institutional theory emphasizes the role institutions and policies play in encouraging or inhibiting the process of change. The theory of institutionalism focuses on the concept of institution. We follow the prominent approach of Douglass C. North who stated that institutions are the rules of the game in a society (North, 1990).

In relation to innovation the institutional theory is linked with the national systems of innovation concept (Lundvall, 1992; Nelson, 1993) and emphasizes the significance of researching the formation and transformation of institutions, with a particular reference to the processes of codification and standardization. Institutional theory can also be extended to eco-innovations, in which economic and institutional factors play essential and important roles in promoting or inhibiting diffusion (del Río \& Unruh, 2007). Referring to its assumptions two mechanisms dedicated to eco-innovations can be identified: 1) harmonization of nationa practices through international legal agreements or supranational law; 2) the coercive imposition of political rules and economic tools.

It should be noted that external conditions created by individual countries become similar. With regard to the EU countries, research confirms the unification of institutional solutions (Busch \& Jörgens, 2005). Convergence in innovation is a pivotal element of a successful European integration as, on the one hand, innovation delivers a key asset for boosting economic competitiveness and, on the other, it supports social and political cohesion. In result, the EU is undertaking a series of initiatives to facilitate innovations (Colombo et al., 2019). The EU's Broad-based Innovation Strategy made major progress in identifying multiple actions as a roadmap for innovation policy and introduced demand-side, as well as supply-side dimensions to policy. Veugelers (2017) argues that there is relative homogeneity between EU countries in terms of the overall range of policy instrument for innovation policy. Bovenberg and Cnossen (2012) indicate that this is not just about international environmental policies, but also adopting similar policy schemes.

Focusing on eco-innovations Costantini et al. (2017) confirm that a match between domestic and foreign policy mixes positively affects eco-innovations. Rennings (2000) emphasizes two peculiarities of eco-innovations, i.e.: the regulatory push/pull impact and the rising significance of social and institutional factors. What is important the former makes eco-innovations more regulatory-dependent than other innovations, while the latter emphasizes the importance of networking with other firms and institutions for eco-innovation (Cainelli et al., 2011). Esty and Porter (2005) show that the most significant considerations for evaluating interest in eco-innovations are the stringency of environmental regulations, the complexity of the regulatory system and the rigor of regulatory compliance. Jacob et al. (2005) report the similar findings. Some authors add international agreement to these factors. It is primarily about international support for investments in pro-ecological technologies (e.g. through the Join Implementation mechanism). However the impact of global environmental agreements on the convergence of eco-innovation remains hard to identify. The existence of the international provision does not automatically suggest similar provision at the national level (Holzinger et al., 2008). Regarding international cooperation, one may argue that it is not the international institution that shapes the countries' policies via its obligations and thus lead to convergence, but that countries which have the same policy preferences tend to join the same institutions. 
Referring to the importance of transnational programs and legal regulations Jang et al. (2015) further emphasize the role of regional programs fostering eco-innovations. In Europe there are: Accelerating Eco-innovation Policies (ECOPOL), Eco-Innovation Action Plan (EcoAP), Environmental Technology Action Plan (ETAP). Non-European countries have been following the measures taken by the European Commission and European governments to develop national strategies and regional roadmaps to stimulate eco-innovations. Studies conducted in Asian countries revealed all 17 countries introduced planning means such as national sustainable development plans or eco-innovation plans for eco-innovations also have Latin America countries (Graf, 2015). These plans comprise national environmental control and green technologies strategies in all target countries. Documents indicate governments are adopting legislative and economic tools to achieve eco-innovation policy targets. The convergence of facilitating innovation solutions was verified by Izsak et al. (2014). They found convergence and very slow-proceeding evolution among the mixes of national innovation policies revealing that countries with differing technological challenges are following similar approaches.

Economic tools are the second mechanism referring to institutional theory. Here, tax incentives are considered the main component of governmental funding for business R\&D in multiple EU member states, like Austria, the Netherlands, Portugal, the United Kingdom. Many countries have adopted sector-oriented programs incorporating direct funding (e.g. subsidies, equity funding) and indirect funding (e.g. tax incentives) instruments (Uniman, 2017). An example of financial support is also official development assistance (ODA), the indicator refers to bilateral ODA allocated to environmentally related sectors. Its calculated as a $\%$ of gross national income, amounts to 0.23 for Japan, 0.13 for Korea, 0.42 for Turkey. Values of this indicator (ODA) for Asian countries do not diverge considerably from the scores of European states: France 0.41, Italy 0.17, Slovenia 0.17. Therefore, it seems that in the case of economic tools they are being unified among countries, which is due to the need to respond to similar ecological problems.

Globally speaking, the development paths for eco technologies in regions seem to be similar. Eco-innovations become global and this phenomenon can be strengthened by following "best practice" policies within specific fields, leading to similarity in results or "path transplantation" (Dawley, 2014). A variety of ecological policy instruments is being put in place for global ecological modernization. Their spillover requires transfrontier transplantation and implementation of innovative designs. This is likely to facilitate convergence. In the light of above considerations, we put following hypotheses:

H1: There exists convergence of eco-innovation drivers among countries.

H2: There exists convergence of eco-innovation outputs among countries.

\section{Data and model}

This study uses the data published by Cleantech Group and WWF $(2012,2014,2017)$. Due to the publication frequency of Global Cleantech Innovation Index and its components, we have selected years 2012, 2014 and 2017 as a research period. The subject of study are 38 countries, including 22 European countries (Austria, Belgium, Bulgaria, Czech Republic, Denmark, 
Finland, France, Germany, Greece, Hungary, Ireland, Italy, Netherlands, Norway, Poland, Portugal, Romania, Slovenia, Spain, Sweden, Switzerland, United Kingdom), 7 Asian countries (China, India, Indonesia, Israel, Japan, Saudi Arabia, South Korea), 3 North American countries (Canada, Mexico, USA), 2 South American countries (Argentina, Brazil), Australia, Russia, South Africa and Turkey. The data have panel structure with 38 units and 3 periods.

To verify the absolute convergence of Innovation Index and its components between countries, we employ a spatial panel data model. The spatial models allow researchers to study the relationships between variables taking into account different spatial patterns. It is known that innovation activity in any country is connected with innovation activities in other countries. A general form of linear spatial panel models is given by the following set of equations (Anselin, 1988; Baltagi et al., 2003):

$$
\begin{aligned}
& y_{i t}=\lambda W y_{i t}+X_{i t} \beta_{(1)}+W X_{i t} \beta_{(2)}+\mu_{i}+u_{i t} ; \\
& u_{i t}=\rho W u_{i t}+\varepsilon_{i t} .
\end{aligned}
$$

This is a two equations model. The first considers spatially lagged dependent variable $y$ as one of the regressors and may also include spatially lagged variables of some or all of the exogenous variables (the term $W X$ ). It also incorporates panel-level effects $\mu_{i}$, which may be either fixed or random. The second equation deals with a spatial model for the stochastic disturbances.

Another option of the spatial panel model with random effects is slightly different than previous one (Kapoor et al., 2007):

$$
\begin{aligned}
& y_{i t}=\lambda W y_{i t}+X_{i t} \beta_{(1)}+W X_{i t} \beta_{(2)}+u_{i t} ; \\
& u_{i t}=\rho W u_{i t}+\mu_{i}+\varepsilon_{i t} .
\end{aligned}
$$

In this variant the panel-level effects $\mu_{i}$ are placed in the error equation and have the same autoregressive form as the time-level errors $\varepsilon_{i t}$.

The spatial panel models for verification $\beta$-convergence hypothesis of eco-innovation used in our study are specified as follows:

$$
\begin{aligned}
& \Delta \dot{y}_{i, t}=\lambda W \Delta \dot{y}_{i, t}+\beta_{1} \dot{y}_{i, t-1}+\beta_{2} W \dot{y}_{i, t-1}+\mu_{i}+u_{i t} ; \\
& u_{i t}=\rho W u_{i t}+\varepsilon_{i t},
\end{aligned}
$$

where $\dot{y}_{i, t}=y_{i, t}-\bar{y}_{t}, \bar{y}_{t}=\frac{1}{N} \sum_{i} y_{i, t}, \Delta \dot{y}_{i, t}=\dot{y}_{i, t}-\dot{y}_{i, t-1}$.

In the above model, which includes the spatially lagged dependent variable $\left(W \Delta \dot{y}_{i, t}\right)$, the proper interpretation of parameters requires estimation of direct and indirect effects. The sign of these effects indicates the existence of convergence or divergence process and the spillovers of eco-innovation. The significant negative direct effect for time lagged level variable $\left(\dot{y}_{i, t-1}\right)$ indicates convergence, while the positive direct effect shows divergence. The significance of indirect effect reveals the impact of eco-innovation in the region on the eco-innovation in neighbouring regions.

The models describe the changes in the eco-innovation index and its components. As convergence variables we apply Global Cleantech Innovation Index (GCII), Inputs to Innovation (INP), Outputs of Innovation (OUT), General Innovation Drivers (GID), Clean- 
tech-Specific Innovation Drivers (CSID), Evidence of Emerging Cleantech Innovation (EECI) and Evidence of Commercialised Cleantech Innovation (ECCI). Global Cleantech Innovation Index tends to measure, to the closest degree possible, the involvement of various entities to not only "push" technology supply but stimulate the "pull" of market demand. For each country, the overall GCII score is calculated on the basis of the average of INP and OUT. The former correspond to the creation of eco-innovation and the latter relate to the country's ability to commercialise eco-innovation. Inputs to eco-innovation are determined by two pillars, i.e. GID, CSID, while outputs of eco-innovation are formed of two other pillars, i.e. EECI and ECCI. The four pillars are composed of a total of 15 indicators, taken from both third party research and Cleantech Group's raw data. The conceptual model of research is presented at Figure 1.

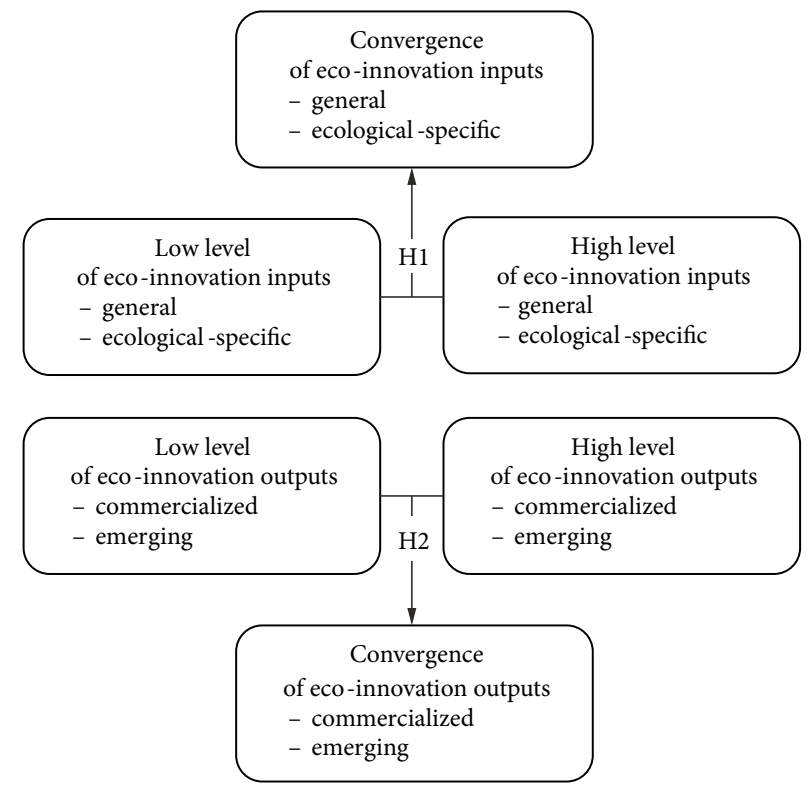

Figure 1. The conceptual model of research

We use two types of spatial weights matrices which reflect the economic and geographic distances between countries. The first one is based on the distance of PKB per capita between countries, and the second one takes into account the location of countries on the continents. The matrices are row-standardized. As a result, the spatially lagged variables are the mean values of them in neighbour regions. The application of these matrices allows us to choose that one which ensure better model adaptation.

\section{Results and discussion}

The average values of Global Cleantech Innovation Index, Inputs to Innovation and Outputs of Innovation for 38 countries in years 2012-2017 are presented in Figure 2, as well as in Figure 3 and Figure 4 . The results are in line with previous works. As regards GCII, the 


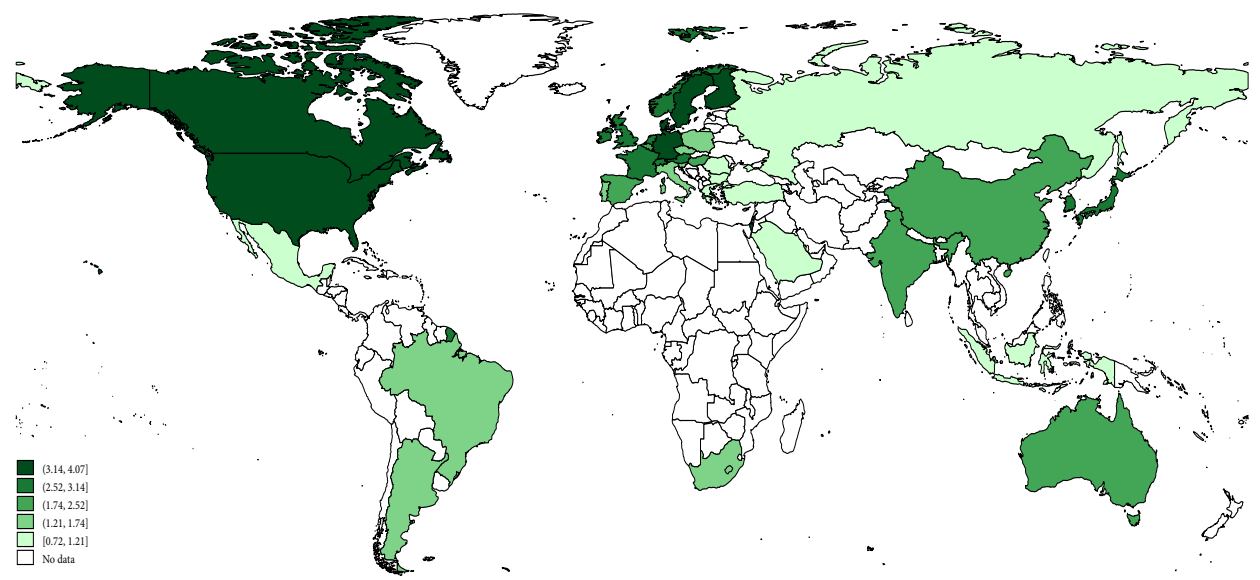

Figure 2. Global Cleantech Innovation Index

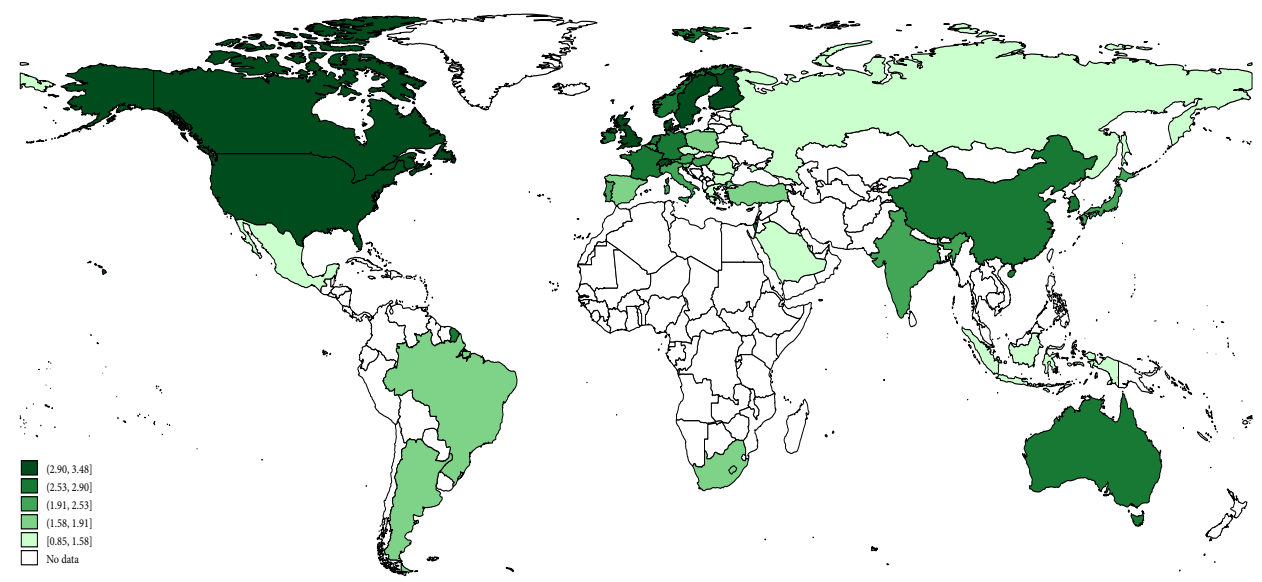

Figure 3. Inputs to Innovation indicator

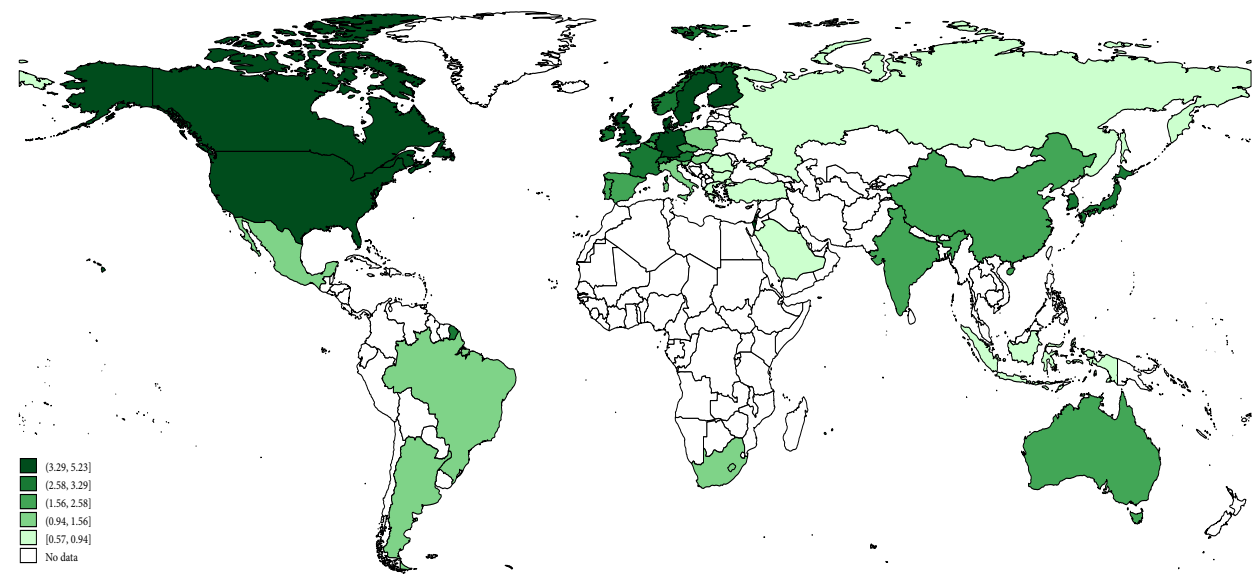

Figure 4. Outputs of Innovation indicator 
index top performers are Denmark, Finland, Sweden, Germany, Canada and the United States. These countries, all lying within North America and Europe, are amongst the top countries for general eco-innovation drivers and outputs. It is quite clear that countries that are facilitating investment in eco-innovations also have the tendency to gain from the commercialization of cleantech companies. In the array of government-backed cleantech-specific innovation determinants, Nordic countries, like Norway, perform well. Additionally, they share relatively high levels of high number of public cleantech enterprises and have a renewable energy consumption. Denmark is a world leader in cleantech-specific drivers and commercialized technological eco-innovations. In commercialized technologies, the country is way ahead of the other countries making up the ranking. In relation to the stimulators of eco-innovations, Denmark, Sweden, Norway, and Finland also reveal significant advantage in the number of private firms involved in the green sectors. These drivers together effectively boost market demand for eco-innovations and supply some capital necessary to scale up inventive start-ups. Eco-innovations in European concerns were induced by environmental regulations. Moreover, high social and market awareness led to eco-innovation activities and performances. Being leaders, European countries launched international programs to create an eco-friendly market. The USA and Canada also give good evidence for the public engagement in that kind of innovations, but possess the largest relative advantage in giving start-ups access to private capital. It is worth noting that the introduction of eco-innovation begins in the regional or domestic markets (most frequently). A progressive government, innovating science and technology, and pioneer enterprises play the role of the stimulator. Such markets are labeled lead markets. With regard to eco-innovation, Canada is the global leader for PEM fuel cells, and hydrogen production and storage.

The GCII low performers are Greece, Romania, Russia, and Saudi Arabia. Low scoring countries typically miss the requisite cleantech-focus in the public enhancement of their national innovation system, through government $\mathrm{R} \& \mathrm{D}$ and supporting policy mechanisms. Developing countries are characterized by the lack of private investment, low eco-innovations exports, and an efficient support framework for the domestic innovation ecosystem. For example, Russia's weak points regarding eco-innovations are especially evident in a regulatory system which is fully non-supportive of that kind of innovation, an absence of green specific industrial clusters and the total lack of private, native investors. Non-awareness of implications and benefits of the eco-innovation in the industry is characteristic for Mexico and Colombia (Sanchez et al., 2018). In India, on the other hand, despite the positive view of entrepreneurship, there is low $\mathrm{R} \& \mathrm{D}$ budget and the lack of presence of ecological organizations and clusters.

Studies conducted by ASEIC (2015) pertaining to the level of development and implementation of eco-innovation revealed a very diversified level in this respect in Asian countries. The following countries scored the lowest on the three-point eco-innovation scale: Vietnam, India, Pakistan, Cambodia, Bangladesh. The highest score was noted for the developed countries, i.e. Australia, Singapore, New Zealand, Japan. For example, in Japan, the government designed and deployed eco-innovation strategies to facilitate their implementation in the power generation sector: solar, wind, geothermal, and hydroelectric power. Simultaneously, technological innovations were introduced in the current power generation sectors, such as, nuclear, fuel and gas, to lessen the burden on the environment. As a consequence, Japan's 
eco-innovation capabilities, the supporting framework and the performance are greater than the average score achieved by the countries on the same level of development. Bangladesh on the other hand is in exactly the opposite situation. This may stem from the fact that ecoinnovation strategies, inc. the green technology, are not clear and one has seen a failure to arrange programs for reducing $\mathrm{CO}_{2}$ and supporting environmental friendly products.

The most improved country performance from 2014 to 2017 was exhibited by Poland, Slovenia, Singapore. This is attributed largely to two significant increases in eco-innovation enablers. Public R\&D investment in Poland now places at the global average. Poland also increased its ranking in the Renewable Energy Country Attractiveness Index. Slovenia has been gradually progressing toward a sustainable lifestyle, the increase in eco-innovation knowledge and public consciousness. Slovenia's eco-innovation covers the pioneering automobile technology stemming from global concerns, efficient electric equipment and mobility, building energy efficiency, and sustainable architecture. The corporation's R\&D spendings have increased in these areas.

In line with our findings Eco-Innovation Scoreboard (European Commission, 2017) shows that Germany has proven to be an efficient innovator. This country shows that in spite of lower early-stage entrepreneurial effort, and low evidence of eco-innovation investment community (relative to GDP) it is still fully capable of achieving high levels of innovation results via a strong established industry and manufacturing sector. Germany is also a spearhead regarding green patents and is also highly placed for jobs in the renewable energy sectors. Meanwhile, Australia is an inefficient innovator (Cleantech Group, 2017). Although the country posseses a very strong entrepreneurial spirit, enhanced by a highly-developed early investment milieu, it does not transform into high innovation performance. The country is lagging behind in commercialized eco-innovations, primarily due to low export income obtained by green sector firms and low employment in renewable energy sectors (relative to total workforce).

We consider different specifications of spatial panel models, including the fixed-effects model, the random-effects model and the random-effects model with autoregressive panel effects. Maximum likelihood method is applied to estimate parameters. We take into account two kinds of spatial matrices calculated on the basis of PKB per capita distances and the location on continents. As suggested by Boschma (2005), a geographical proximity is neither the necessary nor the sufficient condition of knowledge spillover formation. Therefore, other proximity dimensions must be considered to capture knowledge spillover. The choice of appropriate model specification is based on Akaike's and Bayesian information criteria, parameters significance, and significance of spatial terms. Since the application of spatial matrix based on countries' location gives insignificant coefficients, we only use the spatial matrix $(W)$ based on economic distance. The results of the estimation of the models for Global Cleantech Innovation Index, Inputs to Innovation and Outputs of Innovation indicators and effects of explanatory variable are shown in Table 1 and Table 2.

The results of models clearly indicate that eco-innovation activities of countries converge to a steady state (the direct effects of lagged indices are highly negatively significant). These findings give a strong support for the hypothesis 1 and the hypothesis 2 . Additionally, the indirect effects show the spillovers of eco-innovation. It means that the access to the knowledge 
about these environmental innovation activities are easily accessible to possible imitators. It is worth noting that geographical distances between countries are less important in this process than the level of economic development. This finding is in consonance with recent applied spatial econometric considerations, which stress the necessity to go beyond the pure geographical distance measure and to focus more on "economic" dimensions in the selected interconnectivity structure (Paci et al., 2014). As such, economic distance may reflect the reduced transaction costs associated with knowledge flows between geographically remote countries, which have a similar economic structure and lower costs of knowledge gathering and uncertainty.

In order to get detailed information about the absolute $\beta$-convergence of eco-innovation, we study the convergence of detailed indicators on innovation inputs and outputs. The absolute $\beta$-convergence model parameters are estimated for General Innovation Drivers, Cleantech-Specific Innovation Drivers, Evidence of Emerging Cleantech Innovation and Evidence of Commercialised Cleantech Innovation. The results are presented in Table 3 and Table 4.

Detailed indicators, similar to the general indices, strongly converge to the steady state. It should be stressed that there are also the positive spillover effects of eco-innovation input and output measures, aside from ECCI. This finding is in line with common arguments for a boosting role of knowledge externalities in green innovation convergence. Aghion and Jaravel (2015) suggest that there exist complementarities between eco-innovation in developed and in less developed countries. Moreover, in line with Cohen and Levinthal's (1989) theory of absorptive capacity, less developed countries should have an economic and human potential for investing in eco-innovation in order to benefit from knowledge spillovers from the developed countries. The obtained results confirm the occurrence of convergence of ecoinnovation drivers. In the case of general innovation drivers, some countries (e.g. Canada and Finland) act as pathfinders in continually creating climate for getting a business started, also clean technology related. These incentives are followed by other countries. For example, India introduced government initiatives (i.e. Start Up India among others) to create a strong startup ecosystem. It is interesting to note that the lack of the necessary cleantech-focus in the government support may result from financial barriers and depressed investment market (e.g. Greece, Romania, Russia). The change of this situation will require time and a holistic systems approach. Unifying development stimulants leads to the generation of new ecoinnovations and their diffusion. This is reflected, for example, in the growing number of patents in environment-related technologies, with greater growth in developing countries. For example in Belgium technology patents application increased in 2014-2015 by 44\%, Austria - 61\%, Sweden - 33\%, Canada - 16\%, UK - 63\%. For comparison, in developing countries it was: India $-784 \%$, Turkey $-275 \%$, Korea $-436 \%$ (OECD data, 2015). Thus, these countries are catching up with developed ones in terms of the number of eco-innovation patents applied for.

Our results also confirm the occurrence of convergence in relation to implemented innovations. They are consistent with OECD data (for 2014) results on environmental-related technologies that indicate a high level of implementation of this type of technology in countries outside the EU: Japan and Korea - 96, United States - 78, Mexico - 77, and merely slightly lower index in EU countries: Spain - 66, Sweden - 76, Germany - 81. Similar, high 
Table 1. Model parameters estimates for Innovation Indices

\begin{tabular}{|c|c|c|c|}
\hline \multirow{2}{*}{ Variables } & \multicolumn{3}{|c|}{ Dependent Variable $\left(\Delta \dot{y}_{t}\right)$} \\
\hline & $\Delta \mathrm{GC}_{\mathrm{CI}} \mathrm{t}_{\mathrm{t}}$ & $\Delta \mathrm{INP}_{\mathrm{t}}$ & $\Delta \mathrm{OỦT}_{\mathrm{t}}$ \\
\hline$\dot{\mathrm{y}}_{\mathrm{t}-1}$ & $-0.135^{* *}$ & $-0.241^{* * *}$ & $-0.207^{* * *}$ \\
\hline matrix W & & & \\
\hline$\Delta \dot{y}_{t}$ & $0.546^{* * *}$ & $0.495^{* *}$ & 0.403 \\
\hline$\dot{\mathrm{y}}_{\mathrm{t}-1}$ & $0.202^{* *}$ & $0.461^{* * *}$ & $0.238^{* *}$ \\
\hline Wald test of spatial terms ( $\mathrm{p}$-value) & $\begin{array}{c}12.77 \\
(0.005)\end{array}$ & $\begin{array}{c}22.88 \\
(0.000)\end{array}$ & $\begin{array}{c}7.09 \\
(0.069)\end{array}$ \\
\hline
\end{tabular}

Note: ${ }^{*} \mathrm{p}<0.1,{ }^{* *} \mathrm{p}<0.05,{ }^{* * *} \mathrm{p}<0.01$.

Table 2. Direct and indirect effects of lagged Innovation Indices

\begin{tabular}{|l|c|c|c|}
\hline \multirow{2}{*}{\multicolumn{1}{|c|}{ Effect }} & \multicolumn{3}{|c|}{ Dependent Variable $\left(\Delta \dot{\mathrm{y}}_{\mathrm{t}}\right)$} \\
\cline { 2 - 4 } & $\Delta \mathrm{GC}_{\mathrm{CI}}$ & $\Delta \dot{\mathrm{N}}_{\mathrm{t}}$ & $\Delta \mathrm{OỦT}_{\mathrm{t}}$ \\
\hline direct $\left(\dot{\mathrm{y}}_{\mathrm{t}-1}\right)$ & $-0.115^{* *}$ & $-0.194^{* * *}$ & $-0.191^{* * *}$ \\
\hline indirect $\left(\dot{\mathrm{y}}_{\mathrm{t}-1}\right)$ & $0.262^{*}$ & $0.627^{* * *}$ & $0.243^{*}$ \\
\hline
\end{tabular}

Note: ${ }^{*} \mathrm{p}<0.1,{ }^{* *} \mathrm{p}<0.05,{ }^{* *} \mathrm{p}<0.01$.

Table 3. Estimates of model parameters for detailed indicators

\begin{tabular}{|c|c|c|c|c|}
\hline \multirow{2}{*}{ Variables } & \multicolumn{4}{|c|}{ Dependent Variable } \\
\hline & $\Delta \mathrm{GID}_{\mathrm{t}}$ & $\Delta \mathrm{CS} \mathrm{ID}_{\mathrm{t}}$ & $\Delta \mathrm{EECI}_{\mathrm{t}}$ & $\Delta \mathrm{ECCI} \mathrm{t}_{\mathrm{t}}$ \\
\hline$\dot{\mathrm{y}}_{\mathrm{t}-1}$ & $-0.203^{* * *}$ & $-0.508^{* * *}$ & $-0.231^{* * *}$ & $-0.388^{* * *}$ \\
\hline matrix W & & & & \\
\hline$\Delta \dot{y}_{t}$ & 0.286 & $0.656^{* * *}$ & -0.103 & $-0.649^{* * *}$ \\
\hline$\dot{\mathrm{y}}_{\mathrm{t}-1}$ & $0.279^{* *}$ & $0.734^{* * *}$ & 0.156 & -0.272 \\
\hline Wald test of spatial terms (p-value) & $\begin{array}{c}7.98 \\
(0.046)\end{array}$ & $\begin{array}{c}35.70 \\
(0.000)\end{array}$ & $\begin{array}{c}4.94 \\
(0.176)\end{array}$ & $\begin{array}{c}64.11 \\
(0.000)\end{array}$ \\
\hline
\end{tabular}

Note: ${ }^{*} \mathrm{p}<0.1,{ }^{* *} \mathrm{p}<0.05,{ }^{* *} \mathrm{p}<0.01$.

Table 4. Direct and indirect effects of lagged detailed indicators

\begin{tabular}{|c|c|c|c|c|}
\hline \multirow{2}{*}{ Effect } & \multicolumn{4}{|c|}{ Dependent Variable } \\
\hline & $\Delta \mathrm{GID}_{\mathrm{t}}$ & $\Delta \mathrm{CS} \dot{S I D}_{\mathrm{t}}$ & $\Delta \mathrm{EE} \mathrm{EI}_{\mathrm{t}}$ & $\Delta \mathrm{ECCI}_{\mathrm{t}}$ \\
\hline $\operatorname{direct}\left(\dot{y}_{t-1}\right)$ & $-0.187^{* * *}$ & $-0.419^{* * \star}$ & $-0.235^{* * *}$ & $-0.384^{* * *}$ \\
\hline indirect $\left(\dot{\mathrm{y}}_{\mathrm{t}-1}\right)$ & $0.295^{*}$ & $1.077^{\star *}$ & $0.167^{*}$ & 0.400 \\
\hline
\end{tabular}

Note: ${ }^{*} \mathrm{p}<0.1,{ }^{* *} \mathrm{p}<0.05,{ }^{* *} \mathrm{p}<0.01$. 
results were also observed for the adaptation of water-related technologies (Japan - 97, Korea - 97, Mexico - 75, Germany - 80). The measures pertain to eco-innovations which have already been developed, and those with the likelihood of "path-following". The catching-up process of strong cleantech commercialisers can be partially attributed to imports of cleantech commodities. For example, Singapore became a cleantech commercialiser by acting as a strong cleantech trading hub.

From the point of view of practical implications, the important findings are for ecoinnovation followers. Not only are they able to converge to the leaders in relation to the eco-innovation inputs, they are also progressing in the fast pace in relation to eco-innovation outputs. On the one hand, these findings are consistent with the well-known supposition that there exists a positive link between innovation enablers and innovation performance. On the other hand, this link is very sensitive to efficiency in converting inputs. For example, Poland increased public R\&D expenditures and improved renewable energy country attractiveness. Undoubtedly, such policy helps to finance risky projects and creates a climate that encourages green investments, but ultimately its efficiency is verified by late-stage investment in cleantech companies. Finally, the results show that the eco-innovation followers should consider the implementation of innovation policies, in which the key point of eco-innovation efforts is not only learning how to innovate, but learning how to imitate. In fact, imitation usually requires the adaptation of innovation to local circumstances.

\section{Conclusions}

Convergence is a phenomenon empiricalin nature. Countries can converge into a unique steady state, otherwise different investments in knowledge capital give rise to multiple equilibria. The exploration of convergence in regard to the issues of environmental economics is particularly important given the fact that it requires both economic and ecological dynamics to be scrutinized together (Mazzanti, 2018). The present paper examines the convergence of inputs/outputs of eco-innovation in selected countries. The main underlying assumption is that eco-innovation paths are similar between countries. Therefore a convergence of inputs and outputs of eco-innovations emerges. The results fully confirm this phenomenon. The overall level of eco-innovativeness, measured by the GCII index, increases in the sample countries. Specifically, countries with the relatively low level of eco-innovation indices can create/imitate and commercialize eco-innovations faster than ones close to the eco-innovation frontier. In other words, the former countries enjoy an advantage of backwardness. At the same time, there are no escape of more developed countries in relation to developing ones in the long run.

In the analyzed period we found the catching-up processes in General Innovation Drivers (GID) and Cleantech-Specific Innovation Drivers (CSID). It means that the catching-up countries are taking various activities to stimulate eco-innovations. Examples of these activities are governmental strategies (promoting clean technology that covers tax incentives, feed-in tariffs, green bonds), public R\&D expenditures, growth in the number of cleantech firms and cleantech-oriented funds. This is accompanied by positive changes in external conditions that support overall eco-innovativeness - sophistication facilitating innovation 
and positive attitudes towards entrepreneurship. The results also confirmed the convergence (between countries) of commercialized innovations and emerging innovations. In this area, our results are consistent with evidence of commercialized eco-innovation published as part of the Global Cleantech Innovation Index. According to this summary Denmark leads, by a considerable margin, the ranking for commercialized eco-innovations in 2017, placing far ahead of Singapore and Sweden which are in 2nd and 3rd places respectively. The top five are completed by Germany and South Korea, with the differences between the ranking participants below the top five appearing less pronounced, until we hit the bottom five (The Global Innovation Index, 2015). The results of the conducted research confirm that there is a rapprochement between countries in the field of commercialized innovation measures.

As regards the theoretical implications, our study shows that the conceptual support for the explanation of eco-innovation convergence can be found in the innovation diffusion theory, the lead market theory, and the institutional theory. The innovation diffusion theory may be considered the broadest in scope of the three theories presented in this paper. However, it seems to be not sufficient to explain eco-innovation convergence from the input-output perspective of eco-innovation process. Within the system approach to eco-innovation, we use the lead market theory and the institutional theory to give an important starting point for addressing the issue of eco-innovation input and eco-innovation output convergence. Specifically, the complementarity of both theories lies in their capacities to take into account supply side and demand side conditions of eco-innovation convergence. It should be noted that the existing studies do not provide any systematic treatment of eco-innovation convergence. Moreover, they completely neglect spatial dependencies and cross-country influences of eco-innovation activities and performance. In this situation, our paper tries to address this blind spot in the literature.

Our research has some policy implications. First of all, they indicate that countries are learning from each other. This process concerns solutions supporting the stimulation, creation and commercialization of eco-innovations. To increase the level of eco-innovation, it is advisable to use the best institutional solutions (political, legal, economic) introduced by other countries. Imitation or benchmarking seems to be a good way in this direction. Secondly, the country's absorptive capability is important for the convergence process. The increase in absorptive capacity ceteris paribus supports further technological eco-innovations accumulation, that itself supports further development of absorptive capacity. The role of governments in improving the absorptive capacity cannot be over-emphasized. Thirdly, producers need to implement new approaches that contribute significantly to a sustainable growth process and support eco-innovations in a meaningful way. Such approaches require new directions and forms of production patterns. The ignorance of the role of eco-innovations will potentially result in un-intended and undesirable effects for future development.

The research has some limitations that pave the way for future studies. First of all, we focus on the absolute $\beta$-convergence, thus ignoring the structural characteristics of countries, which could be nontrivial for convergence processes. In this regard, we suggest testing the conditional convergence, which takes into account the importance of some stylized factors, i.e. political and legal norms, ecological awareness, national culture, etc. in the process of eco-innovation introduction and diffusion. On the other hand, a remarkable possible exten- 
sion of our research in this dimension would be to study the club convergence in the groups of countries with similar institutional, economic, and geographical characteristics affecting eco-innovation development paths. Second, we have limited the sample size due to data availability. Future studies may attempt to enlarge the sample size at the expense of research scope. Finally, we apply two types of spatial weights matrices which reflect the economic and geographic distances between countries. In this situation, it would be reasonable to extend our research to incorporate other dimensions of proximity (i.e. institutional, cognitive or technological) across countries and find their impact on knowledge spillovers.

\section{References}

Aghion, P., \& Jaravel, X. (2015). Knowledge spillovers, innovation and growth. Economic Journal, 125, 533-573. https://doi.org/10.1111/ecoj.12199

Aldieri, L., Kotsemir, M., \& Vinci, C. P. (2020). The role of environmental innovation through the technological proximity in the implementation of the sustainable development. Business Strategy \& Environment, 29, 493-502. https://doi.org/10.1002/bse.2382

Aldieri, L., Sena, V., \& Vinci, C. P. (2018). Domestic R\&D spillovers and absorptive capacity: Some evidence for US, Europe and Japan. International Journal of Production Economics, 198, 38-49. https://doi.org/10.1016/j.ijpe.2018.01.015

Anselin, L. (1988). Spatial econometrics: methods and models. Kluwer Academic. https://doi.org/10.1007/978-94-015-7799-1

Antonioli, D., Borghesi, S., \& Mazzanti, M. (2016). Are regional systems greening the economy? Local spillovers, green innovations and firm's economic performances. Economics of Innovation and New Technolology, 25(7), 692-713. https://doi.org/10.1080/10438599.2015.1127557

Arundel, A., \& Kemp, R. (2009). Measuring eco-innovation (Working paper). UNU-MERIT, Maastricht.

ASEM Eco-Innovation Index. (2015). Measuring sustainable future for Asia and Europe. http://www. aseic.org

Baltagi, B., Song, S. H., \& Koh, W. (2003). Testing panel data regression models with spatial error correlation. Journal of Economics, 117, 123-150. https://doi.org/10.1016/S0304-4076(03)00120-9

Bartlett, D., \& Trifilova, A. (2010). Green technology and eco-innovation: Seven case-studies from a Russian manufacturing context. Journal of Manufacturing Technology Management, 21, 910-929. https://doi.org/10.1108/17410381011086757

Beise, M., \& Rennings, K. (2005). Lead markets and regulation: a framework for analyzing the international diffusion of environmental innovations. Ecological Economics, 52(1), 5-17. https://doi.org/10.1016/j.ecolecon.2004.06.007

Bimonte, S. (2009). Growth and environmental quality: Testing the double convergence hypothesis. Ecological Economics, 68(8-9), 2406-2411. https://doi.org/10.1016/j.ecolecon.2009.03.020

Bloomberg New Energy Finance. (2017). New energy pioneers. https://about.bnef.com/blog/10-companies-chosen-2017-new-energy-pioneers-tenth-annual-bloomberg-new-energy-finance-summit-new-york-city/

Borghesi, S., Costantini, V., Crespi, F., \& Mazzanti, M. (2013). Environmental innovation and socio economicdynamics in institutional and policy contexts. Journal of Evolutionary Economics, 23, 241-245. https://doi.org/10.1007/s00191-013-0309-5

Boschma, R. (2005). Proximity and innovation: A critical assessment. Regional Studies, 39, 61-74. https://doi.org/10.1080/0034340052000320887 
Bovenberg, L., \& Cnossen, S. (2012). Public economics and the environment in an imperfect world. Springer Science \& Business Media.

Busch, P. O., \& Jörgens, H. (2005). International patterns of environmental policy change and convergence. Environmental Policy and Governance, 15(2), 80-101. https://doi.org/10.1002/eet.374

Cainelli, G., Mazzanti, M., \& Zoboli, R. (2011). Environmental innovations, complementarity and local/ global cooperation: evidence from North-East Italian industry. International Journal of Technology, Policy and Management, 11(3-4), 328-368. https://doi.org/10.1504/IJTPM.2011.042090

Camarero, M., Picazo-Tadeo, A. J., \& Tamarit, C. (2008). Is the environmental performance of industrialized countries converging? A 'SURE' approach to testing for convergence. Ecological Economics, 66(4), 653-661. https://doi.org/10.1016/j.ecolecon.2007.10.024

Charter, M., \& Clark, T. (2007). Sustainable innovation. The Centre for Sustainable Design, Farnham.

Cheng, C. C. J., Yang, C., \& Sheu, C. (2014). The link between eco-innovation and business performance: A Taiwanese industry context. Journal of Cleaner Production, 64, 81-90.

https://doi.org/10.1016/j.jclepro.2013.09.050

Cleantech Group and WWF. (2012). The Global Cleantech Innovation Index 2012.

Cleantech Group and WWF. (2014). The Global Cleantech Innovation Index 2014. Climate Neutral Company.

Cleantech Group and WWF. (2017). The Global Cleantech Innovation Index 2017. Åtta45.

Cohen, W. M., \& Levinthal, D. A. (1989). Innovation and learning: the two faces of R \& D. The Economic Journal, 99(397), 569-596. https://doi.org/10.2307/2233763

Colombo, L. A., Pansera, M., \& Owen, R. (2019). The discourse of eco-innovation in the European Union: An analysis of the Eco-Innovation Action Plan and Horizon 2020. Journal of Cleaner Production, 214, 653-665. https://doi.org/10.1016/j.jclepro.2018.12.150

Corredoira, R. A., \& Rosenkopf, L. (2010). Should auld acquaintance be forgot? The reverse transfer of knowledge through mobility ties. Strategic Management Journal, 31(2), 159-181.

https://doi.org/10.1002/smj.803

Costantini, V., Crespi, F., \& Palma, A. (2017). Characterizing the policy mix and its impact on ecoinnovation: A patent analysis of energy-efficient technologies. Research Policy, 46, 799-819. https://doi.org/10.1016/j.respol.2017.02.004

Cuerva, M. C., Triguero-Cano, Á., \& Córcoles, D. (2014). Drivers of green and non-green innovation: Empirical evidence in Low-Tech SMEs. Journal of Cleaner Production, 68, 104-113. https://doi.org/10.1016/j.jclepro.2013.10.049

Dahan, S., \& Yusof, S. (2020). Review and proposed eco-process innovation performance framework. International Journal of Sustainable Engineering, 13(2), 123-139. https://doi.org/10.1080/19397038.2019.1644387

Dawley, S. (2014). Creating new paths? Offshore wind, policy activism, and peripheral region development. Economic Geography, 90, 91-112. https://doi.org/10.1111/ecge.12028

del Río, P., \& Unruh, G. (2007). Overcoming the lock-out of renewable energy technologies in Spain: the cases of wind and solar electricity. Renewable \& Sustainable Energy Reviews, 11, 1498-1513. https://doi.org/10.1016/j.rser.2005.12.003

del Río, P., Romero-Jordán, D., \& Peñasco, C. (2017). Analysing firm-specific and type-specific determinants of eco-innovation. Technological Economic and Development of Economy, 23(2), 270-295. https://doi.org/10.3846/20294913.2015.1072749

Dong, Y., Wang, X., Jin, J., Qiao, Y., \& Shi, L. (2014). Effects of eco-innovation typology on its performance: Empirical evidence from Chinese enterprises. Journal of Engineering and Technology Management, 34, 78-98. https://doi.org/10.1016/j.jengtecman.2013.11.001 
Esty, D. C., \& Porter, M. E. (2005). National environmental performance: an empirical analysis of policy results and determinants. Environment and Development Economics, 10(4), 391-434. https://doi.org/10.1017/S1355770X05002275

European Commission. (2010). Europe 2020. A strategy for smart, sustainable and inclusive growth. European Commission, Brussels.

European Commission. (2017). The Eco-Innovation Scoreboard. European Commission. https://ec.europa.eu/environment/ecoap/indicators/index_en

Evans, P. B. (1995). Embedded autonomy. States and industrial transformation. Princeton University Press. https://doi.org/10.1515/9781400821723

Faria, L. G. D., \& Andersen, M. M. (2017). Sectoral dynamics and technological convergence: an evolutionary analysis of eco-innovation in the automotive sector. Industry and Innovation, 24(8), 837-857. https://doi.org/10.1080/13662716.2017.1319801

Fritz, M. (2017, June 20-22). European Union Policy on nature based solutions and green infrastructure [Conference Presentation]. World Green Infrastructure Congress WGIC, Berlin, Germany.

Ganapathy, S. P., Natarajan, J., Gunasekaran, A., \& Subramanian, N. (2014). Influence of eco-innovation on Indian manufacturing sector sustainable performance. International Journal of Sustainable Development \& World Ecology, 21, 198-209. https://doi.org/10.1080/13504509.2014.907832

Gente, V., \& Pattanaro, G. (2019). The place of eco-innovation in the current sustainability debate. Waste Management, 88, 96-101. https://doi.org/10.1016/j.wasman.2019.03.026

Gielen, F. (2018). Clean energy innovation: could Europe become the world leader? Scitech Europa. https://www.scitecheuropa.eu/clean-energy-innovation/89868/

Global Sustainable Investment Alliance. (2016). Global sustainable investment review 2016. http://www. gsi-alliance.org/wp-content/uploads/2017/03/GSIR_Review2016.F.pdf

Graf, P. (2015). Eco-innovation: a new paradigm for Latin America. Gestão e Desenvolvimento, Novo Hamburgo, Ano XII, 12(1), 148-159.

Hallenga-Brink, S. C., \& Brezet, J. C. (2005). The sustainable innovation design diamond for microsized enterprises in tourism. Journal of Cleaner Production, 13(2), 141-149. https://doi.org/10.1016/j.jclepro.2003.12.021

Hazarika, N., \& Zhang, X. (2019). Evolving theories of eco-innovation: A systematic review. Sustainable Production and Consumption, 19, 64-78. https://doi.org/10.1016/j.spc.2019.03.002

Hojnik, J., \& Ruzzier, M. (2016). What drives eco-innovation? A review of an emerging literature. Environmental Innovation and Societal Transition, 19, 31-41. https://doi.org/10.1016/j.eist.2015.09.006

Holzinger, K., Knill, C., \& Sommerer, T. (2008). Environmental policy convergence: the impact of international harmonization, transnational communication and regulatory competition. International Organization, 62(4), 553-587. https://doi.org/10.1017/S002081830808020X

Howlett, R. J., Gabrys, B., Musial-Gabrys, K., \& Roach, J. (Eds.). (2013). Innovation through knowledge transfer. Springer-Verlag. https://doi.org/10.1007/978-3-642-34219-6

Huber, J. (2008). Pioneer countries and the global diffusion of environmental innovations: Theses from the viewpoint of ecological modernisation theory. Global Environmental Change, 18(3), 360-367. https://doi.org/10.1016/j.gloenvcha.2008.03.004

Huppes, G., Kleijn, R., Huele, R., Ekins, P., Shaw, B., Esders, M., \& Schaltegger, S. (2008). Measuring eco-innovation: framework and typology of indicators based on causal chains: final report of the ECODRIVE project. European Commission, London.

Izsak, K., Markianidou, P., \& Radošević, S. (2014). Convergence among national innovation policy mixes in Europe - an analysis of research and innovation policy measures in the period 2004-2012 (Working Paper No. 3.11, Series GRINCOH). http://www.grincoh.eu/media/serie_3_knowledge_innovation_technolog/grincoh_wp_3.11_izsak_markianidou_radosevic.pdf 
Jacob, K., Beise, M., Blazajcak, J., Edler, D., Haum, R., Jänicke, M., Löw, T., Petschow, U., \& Rennings, K. (2005). Lead markets for environmental innovations. Physica Verlag.

Jang, E. K., Park, M. S., Roh, T. W., \& Han, K. J. (2015). Policy instruments for eco-innovation in Asian countries. Sustainability, 7, 12586-12614. https://doi.org/10.3390/su70912586

Jang, Y. (2009). Technological convergence through industrial research collaboration: a comparative analysis between the U.S. and Korea. Asian Journal of Technology Innovation, 17, 101-120. https://doi.org/10.1080/19761597.2009.9668668

Jänicke, M. (2008). Ecological modernization: new perspectives. Journal of Cleaner Production, 16(5), 557-565. https://doi.org/10.1016/j.jclepro.2007.02.011

Kapoor, M., Kelejian, H. H., \& Prucha, I. R. (2007). Panel data models with spatially correlated error components. Journal of Economics, 140, 97-130. https://doi.org/10.1016/j.jeconom.2006.09.004

Kates, R. W., Parris, T. M., \& Leiserowitz, A. A. (2005). What is sustainable development? Goals, indicators, values, and practice. Environment: Science and Policy for Sustainable Development, 47(3), 8-21. https://doi.org/10.1080/00139157.2005.10524444

Kemp, R., \& Pearson, P. (2007). Final report MEI project about measuring eco-innovation. UM-MERIT, Maastricht.

Kijek, T., \& Kasztelan, A. (2013). Eco-innovation as a factor of sustainable development. Problemy Ekorozwoju, 8(2), 103-112.

Kotnour, T., \& Bollo, T. R. (2011). Strategic management of a transformation in a multi-program technology program involving convergence and divergence of programs: observations from NASA. International Journal of Technology Management, 53(2-4), 257-272. https://doi.org/10.1504/IJTM.2011.038593

Kuhn, T. (1977). The essential tension: selected studies in scientific tradition and change. University of Chicago Press. https://doi.org/10.7208/chicago/9780226217239.001.0001

Lee, G. K. (2007). The significance of network resources in the race to enter emerging product markets: The convergence of telephony communications and computer networking, 1989-2001. Strategic Management Journal, 28(1), 17-37. https://doi.org/10.1002/smj.566

Lee, K. R. (2015). Toward a new paradigm of technological innovation: convergence innovation. Asian Journal of Technology Innovation, 23, 1-8. https://doi.org/10.1080/19761597.2015.1019226

Lee, K. R. (2018). Managing convergence in innovation. Routledge.

Leitner, A., Wehrmeyer, W., \& France, C. (2010). The impact of regulation and policy on radical eco-innovation. Management Research Review, 33, 1022-1041. https://doi.org/10.1108/01409171011085877

Lema, R., Sagar, A., \& Zhou, Y. (2016). Convergence or divergence? Wind power innovation paths in Europe and Asia. Science and Public Policy, 43(3), 400-413. https://doi.org/10.1093/scipol/scv049

Lema, R., Johnson, B., Andersen, A. D., Lundvall, B.-Å., \& Chaudhary, A. (2014). Low-carbon innovation and development. Aalborg University Press.

Lundvall, B.-Å. (Ed.). (1992). National systems of innovation: towards a theory of innovation and interactive learning. Pinter Publishers.

Markard, J., Raven, R., \& Truffer, B. (2012). Sustainability transitions: an emerging field of research and its prospects. Research Policy, 41(6), 955-967. https://doi.org/10.1016/j.respol.2012.02.013

Mazzanti, M. (2018). Eco-innovation and sustainability: dynamic trends, geography and policies. Journal of Environmental Planning and Management, 61, 1851-1860. https://doi.org/10.1080/09640568.2018.1486290

Mohamed, M., Fung, H. N., \& Wong, C. Y. (2015). Convergence innovation in railway technology: how ERL of Malaysia attained its co-evolution structure for systemic development.' Asian Journal of Technology Innovation, 23(S1), 93-108. https://doi.org/10.1080/19761597.2015.1012787 
Montalvo, C., Diaz Lopez, F. J., \& Brandes, F. (2011). Potential for eco-innovation in nine sectors of the European economy. Europe INNOVA Sectoral Innovation Watch, Brussel.

Motta, W. H., Prado, P. A., \& Issberner, L. R. (2017). Life cycle assessment and the eco innovation generation. [Conference Presentation]. PLATE Conference.

Nelson, R. R. (1993). National innovation systems: a comparative analysis. University of Illinois at Urbana-Champaign's Academy for Entrepreneurial Leadership Historical Research Reference in Entrepreneurship.

Neto, A. S., Jabbour, C. J., \& de Sousa Jabbour, A. B. (2014). Green training supporting eco-innovation in three Brazilian companies: practices and levels of integration. Industrial and Commercial Training, 46(7), 387-392. https://doi.org/10.1108/ICT-02-2014-0010

North, D. C. (1990). Institutions, institutional change and economic performance (28th ed.). Cambridge University Press. https://doi.org/10.1017/CBO9780511808678

OECD. (2009). Sustainable manufacturing and eco-innovation: framework, practices and measurement. OECD Publishing, Paris.

O'Hare, J. A. (2010). Eco-innovation tools for the early stages: an industry-based investigation of tool customization and introduction [Doctoral Thesis]. University of Bath, Department of Mechanical Engineering.

Paci, R., Marrocu, E., \& Usai S. (2014). The complementary effects of proximity dimensions on knowledge spillovers. Spatial Economic Analysis, 9(1), 9-30.

https://doi.org/10.1080/17421772.2013.856518

Quitzow, R., Walz, R., Kohler, J., \& Rennings, K. (2014). The concept of “lead markets" revisited: Contribution to environmental innovation theory. Environmental Innovation and Societal Transitions, 10, 4-19. https://doi.org/10.1016/j.eist.2013.11.002

Rao, K. U., \& Kishore, V. V. N. (2010). Are view of technology diffusion models with special reference to renewable energy technologies. Renewable and Sustainable Energy Reviews, 14(3), 1070-1078. https://doi.org/10.1016/j.rser.2009.11.007

Rennings, K. (2000). Redefining innovation - eco-innovation research and the contribution from ecological economics. Ecological Economics, 32(2), 319-332.

https://doi.org/10.1016/S0921-8009(99)00112-3

Rennings, K. (2014). Introduction: Global diffusion of environmental innovations. Environmental Innovation and Societal Transitions, 10, 1-3. https://doi.org/10.1016/j.eist.2013.12.005

Rogers, E. M. (2003). Diffusion of innovations (5th ed.). The Free Press.

Sáez-Martínez, F. J., Díaz-García, C., \& Gonzalez-Moreno, A. (2016). Firm technological trajectory as a driver of eco-innovation in young small and medium-sized enterprises. Journal of Cleaner Technology, 138(1), 28-37. https://doi.org/10.1016/j.jclepro.2016.04.108

Salvati, L., \& Zitti, M. (2008). Regional convergence of environmental variables: Empirical evidences from land degradation. Ecological Economics, 68(1-2), 162-168. https://doi.org/10.1016/j.ecolecon.2008.02.018

Sanchez, P. J. R., Gonzalez, M. H., \& Arias, J. C. B. (2018). Eco-innovation and sustainable production in developing countries. Cases Colombia and Mexico. Economy \& Business Journal, 12, 228-238.

Sarkar, A. N. (2013). Promoting eco-innovations to leverage sustainable development of eco-industry and green growth. European Journal of Sustainable Development, 2(1), 171-224. https://doi.org/10.14207/ejsd.2013.v2n1p171

Schiederig, T., Tietze, F., \& Herstatt, C. (2012). Green innovation in technology and innovation management - An exploratory literature review. R\&D Management, 42, 180-192.

https://doi.org/10.1111/j.1467-9310.2011.00672.x 
Schmitz, H., \& Altenburg, T. (2016). Innovation paths in Europe and Asia: Divergence or convergence? Science and Public Policy, 43(4), 454-463.

Shin, D. H. (2010). Convergence and divergence: policy making about the convergence of technology in Korea. Government Information Quarterly, 27(2), 147-160. https://doi.org/10.1016/j.giq.2009.11.001

Sierzchula, W., Bakker, S., Maat, K., \& van Wee, B. (2012). Technological diversity of emerging ecoinnovations: A case study of the automobile industry. Journal of Cleaner Production, 37, 211-220. https://doi.org/10.1016/j.jclepro.2012.07.011

Statista. (2018). Statistics and market data about energy \& environmental services. https://www.statista. com/markets/408/energy-environmental-services/

Suh, S., Lee, K., \& Ha, S. (2005). Eco-efficiency for pollution prevention in small to medium-sized enterprises - A case from South Korea. Journal of Industrial Ecology, 9, 223-240. https://doi.org/10.1162/108819805775247918

The Global Innovation Index. (2015). Report. Cleantech Group and WWF.

Triguero, A., Moreno-Mondéjar, L., \& Davia, M. A. (2013). Drivers of different types of eco-innovation in European SMEs. Ecological Economics, 92, 25-33. https://doi.org/10.1016/j.ecolecon.2013.04.009

Truffer, B., \& Coenen, L. (2012). Environmental innovation and sustainability transitions in regional studies. Regional Studies, 46(1), 1-21. https://doi.org/10.1080/00343404.2012.646164

Tsai, K. H., \& Liao, Y. C. (2017). Sustainability strategy and eco-innovation: a moderation model. Business Strategy and Environment, 26(4), 426-437. https://doi.org/10.1002/bse.1926

Uniman. (2017). Overview of eleven member states innovation policies (Project industrial innovation in transition, No. 649351). European Union.

Veugelers, R. (2017). Missing convergence in innovation capacity in the EU: facts and policy implications. (Fellowship initiative "Challenges to integrated markets", Discussion Paper No. 066). European Union. 